\title{
Testing the Existence of January Effect in Indonesia and Kuala Lumpur Shari'ah Compliance
}

\author{
Helma Malini \\ Faculty of Economy \\ Department of Management \\ Tanjungpura University \\ West Kalimantan \\ Indonesia \\ Mohamad Jais \\ Faculty of Economics and Bussines \\ University Malaysia Sarawak \\ Department of Management and Finance \\ Sarawak \\ Malaysia
}

\begin{abstract}
This paper investigates the existence of January Effect in Indonesia and Malaysia Shari'ah stock market and the implication for stock market efficiency. Shari'ah Compliance is relatively a new industry both for Indonesia and Malaysia, although the growth is continously increasing over the year. There are significant differences between investing in Shari'ah compliant than the conventional stock market, since Shari'ah capital market have to followed a set of rules form the stock exchange and also followed Islamic capital market law and principles. Study that focusing about Shari'ah compliance both for Indonesia and Malaysia is still rare, that is why this study taking one step further by examining the january effect in Indonesia and Malaysia Shariah compliance. Regression model with dummy variables and monthly price of companies that classified in the Indonesia and Malaysia Shari'ah compliance from January 2000 to December 2012 to test the Janaury effect in the stock return of Indonesia Shari'ah compliance and Kuala Lumpur Shari'ah compliance. It was empirically found that, although Janaury anomaly does not exist in Indonesia Shari'ah compliance and in Kuala Lumpur Shari'ah compliance. Other result showed that both Shari'ah compliance also enjoyed significant return in other month beside January which is July for Indonesia and September, October and November for Malaysia, which raises question against Efficient Market Hypothesis (EMH).
\end{abstract}

Keywords: Calendar effects, Indonesia and Malaysia Shari'ah compliance, January Effect, Efficient Market Hypothesis 


\section{Introduction}

For almost ten years after the publication of Fama's classic exposition in 1970, the Efficient Markets Hypothesis (EMH) dominated the academic and business scene. According to this hypothesis the market is efficient if its price are formed on the basis of all available information. Stock market is efficient not only if all relevant information about the company are incorporated into stock price, but also influence investor rationality in taking investment decisions.

The assumption that investors are rational and therefore value investments rationally - that is, by calculating the net present values of future cash flows, appropriately discounted for risk has not been supported by empirical evidence. Rather the evidence shows that investors are affected by herd instinct, a tendency to "churn" their portfolios, and a tendency to under-react or over-react to news or asymmetrical judgements about the causes of previous profits and losses. Furthermore, many alleged anomalies have been detected in the patterns of historical share prices. The best known are calendar anomalies.

The objective of this study is to investigated the existence of "turn-of-the-year" or January effect in Islamic capital market or familiar with the term of Shari'ah compliant. The January effects a seasonal irregularity of the financial market where tock prices tend to fall towards the end of December and then recuperate quickly in the first month of the New year, i.e., January.

Monthly value of Indonesia and Malaysia Shari'ah compliance for ten years from 2000 to 2012, has been employed for detecting January effect of Shari'ah compliance from both countries. Regression modles coupled with dummy variables is used to test the existence of January effect. The reason for choosing Shari'ah compliant as the backgorund of study is looking at the growth of the industry both in Indonesia and Malaysia. In Indonesia about $86.1 \%$ of 230 million of population are Muslim, which makes Indonesia the biggest Muslim majority country in the world. Therefore, Indonesia offers bright prospects for the development of Islamic capital market. Based on the 2012 Indonesian Islamic Capital Report, the development of Shari'ah stocks on the Indonesia Shar'iah Securities List shows an increasing number from 173 in 2007 to 253 Shari'ah stocks in 2012. As March 2012, the percentage of Shari'ah stocks have exceeded the percentage of conventional stocks at $50.7 \%$. While in Malaysia the growth of Shari'ah compliance is very significant showed by number of listed companies in 2012 were 766 and the percentage of exceeded the percentage of conventional stocks at $82.3 \%$. Thus making comparison between Indonesia and Malaysia Shari'ah compliance are appropriate since not only both countries are geographically closed but also of the strong correlation and integration of Shari'ah stock market in both countries.

\section{Literature Review}

The January effect is a calendar-related market anomaly in the financial market where financial security prices increase in the month of January. This creates an opportunity for investors to buy stock for lower prices before January and sell them after their value increases. Therefore, the main characteristics of the January Effect are an increase in buying securities before the end of the year for a lower price, and selling them in January to generate profit from the price differences. The recurrent nature of this anomaly suggest that the market is not efficient, as market efficiency would suggest that this effect should disappear. Keim 
(1983) shows that a large part of the year return is due to January effect and especially to the excess return obtained in the first days of trading in January; the relation between the company size and the excess return being negative. Horowitz, Loughran and Savin (2000) are consistent with the existence of January effect - the existence of higher average return in January in comparison with the average returns for the rest of the year's months, but their paper does not support the negative relation between the excess return in January and the company's size.

January effect has also been detected in Canada (Berges, McConnell, \& Schlarbaum, 1984), Japan (Kato \& Schallheim, 1985), Malaysian (Nassir \& Mohammad, 1987), U.K. (Mills \& Coutts, 1995), Greece (Mills, Siriopoulos, Markellos \& Harizanis, 2000), Chile, Greece, Korea, Taiwan and Turkey (Fountas \& Segredakis, 2002), India (Pandey, 2002), Sweden (Hellstrom, 2002), Nepal (Bahadur \& Joshi, 2005), Poland, Romania, Hungary and Slovakia (Asteriou \& Kovetsos, 2006), Argentina (Rossi, 2007). However, conflicting results are also available. For instance, January effect in Jordon (Maghayereh, 2003), Greece (Flores, 2008), Brazil, Chile and Mexico (Rossi, 2007) wasn’t detected.

December, and new information effect. Tax-loss selling hypothesis (Branch, 1977) asserts that in December, i.e., end of tax year, investors tend to sell out the stocks held to realize capital losses. This helps them in reducing tax paid by them on their gains. As a result of this downward trend in market, stock prices go down. As the new tax year starts in January, investors again start to buy stocks and this upward drift pushes the stock prices up. Window dressing hypothesis (Haugen \& Lakonishok, 1988) posits that, to manipulate their performance, fund managers, avoid showing losers at their credit at year end, and thus start selling loser stocks from their fund and let only the winners stay in their portfolio. However, on January, fund managers reverse their action and start selling winners and put small stocks back in the portfolio. These window dressing actions by the fund managers create artificial downward pressure (and low returns) in December and upward pressure in the market (and high returns) in January.

\section{III.Research Method}

\subsection{Data}

This Section offers a brief description of the research method and the data set. Using daily closing price of Indonesia Shari'ah compliance and Malaysia shari'ah compliance from the period of $2000: 1$ to $2012: 12$. The companies that classified as Shari'ah in Indonesia are 214 companies while in Malaysia there are 766 companies.

Since Indonesia and Malaysia Shari'ah compliance has experienced major structural changes with the potential for affecting market efficiency, we divide our chosen sample period into three following sub periods of differing market stages :

1. January 1, 2000 - 2004; periods during its early stages of Indonesia Shar'iah compliance and Malaysia Shari'ah compliance development. In the early stages showed that many turbulances influence the establishment of shari'ah indices in both countries specially in term of policy and socialization. 
2. January 1, 2005 - 2008; periods during which the Indonesia Shari'ah Compliance and Kuala Lumpur Shari'ah compliance stock market grew significantly in size and number. The growth of Indonesia Shari'ah Compliance and Malaysia Shari'ah compliance are because both countries has implemented and formulated socialization process.

3. January 1, $2009-2012$ periods after market crash. The period after market crash showed that both shari'ah index in Indonesia and Malaysia are reluctant to several crisis such as Subprime mortgage crisis in US and debt crisis in Europe.

The stages allowed us to test for the presence of January effect over shorts period of time. It also enables us to determine whether there was January effect in the Indonesia and Malaysia Shari'ah compliant.

\subsection{Methodology}

Monthly return of DSI Index is calculated as the natural log of [today's Index Value / previous day's Index Value]:

$$
R t=\operatorname{In}\left(\frac{p_{t}}{p_{t-1}}\right)
$$

Where:

$R t=$ Monthly return of ISC and KLSC

$P t=$ Closing value of ISC and KLSC Index at time $t$.

$P t-1=$ Closing value of ISC and KLSC Index at time $t-1$.

The reasons to choose logarithm returns over general return are justified by both theoretically and empirically. Theoretically, logarithmic returns are analytically more tractable when linking together sub-period returns to form returns over longer intervals. Empirically, logarithmic returns are more likely to be normally distributed which is prior condition of standard statistical techniques (Strong, 1992).

To test the existence of monthly seasonality, the following basic regression model is used:

$$
\begin{aligned}
R t=\quad & C+\beta 2 \mathrm{D} f e b+\beta 3 \text { Dmar }+\beta 4 \text { Dapr }+\beta 5 \text { Dmay }+\beta 6 \text { Djun }+\beta 7 \text { Djul }+\beta 8 \text { Daug } \\
& +\beta 9 D \text { sep }+\beta 10 \text { Doct }+\beta 11 \text { Dnov }+\beta 12 D d e s+\mu^{t}
\end{aligned}
$$

Where, $R t$ is the monthly return and the intercept term, $C$, indicates the average return for January. $D i$ is a dummy variable that takes the value of 1 in month and $i$ zero otherwise. For instance, $D F e b=1$ if the return is on February and 0 otherwise; DMar = 1 if the return is on March and 0 otherwise; $D D e c=1$ if the return is on December and 0 otherwise and so on. The OLS coefficients $\beta_{2}$ to $\beta_{12}$ indicate the difference in return between January and the $i$ th month of the year. The stochastic disturbance term is denoted by $\mu^{t}$ 


\section{Result and Discussion}

\section{Indonesia Shari'ah Compliance Monthly Return From 2000-2012}

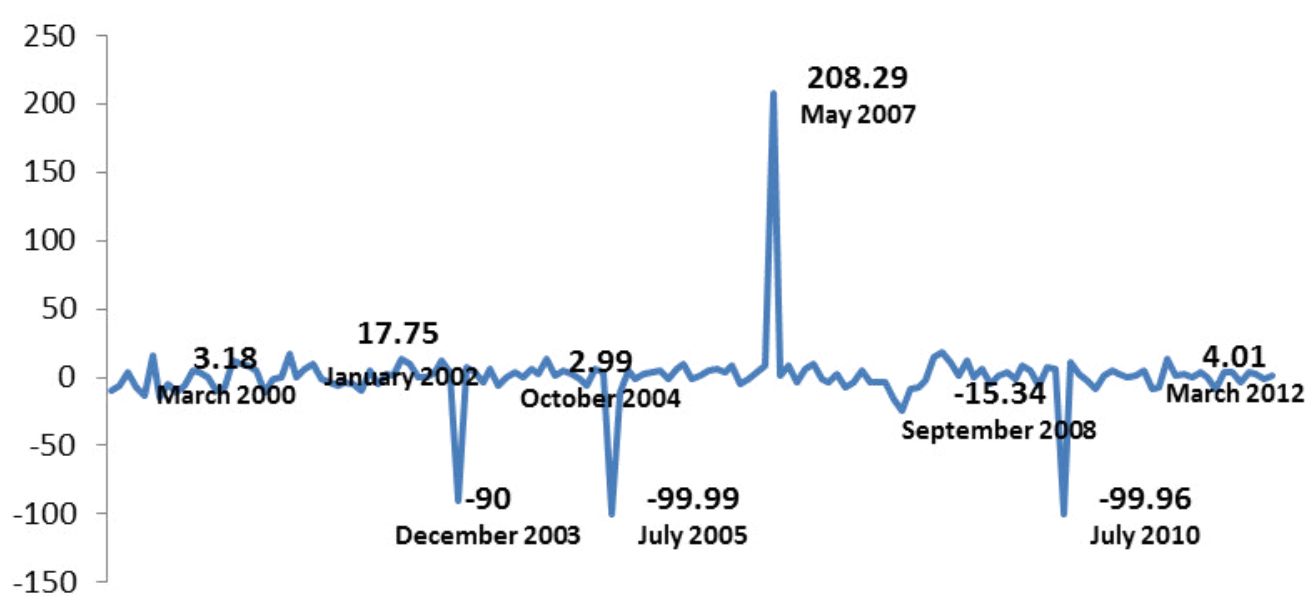

Figure 1. ISC (Indonesia Shari'ah Compliance) Monthly Return from 2000-2012

Figure 1 showed the monthly return for Indonesia Shariah compliance from the year 2000-2012. The monthly return from the January until December showed volatility. The graphics noted in certain months Indonesia having increasing and decreasing towards their monthly return. On average month of the year showing stability of monthly return. May 2007 showed increasing of the monthly return at 208.29, while on December 2003, July 2005, and July 2010 are showing decreasing in the monthly return with average point of -99.00 . From the behavioural investor perspective we can see that investor the movement related to investor behaviour particularly during crisis and the increasing of oil prices in Indonesia that happened in 2004, which was the first democration general election in Indonesia, continoued with the increasing of oil price in 2006 and subprime mortgage crisis in 2008.

\section{Kuala Lumpur Shari'ah Compliance Monthly Return} From 2000-2012

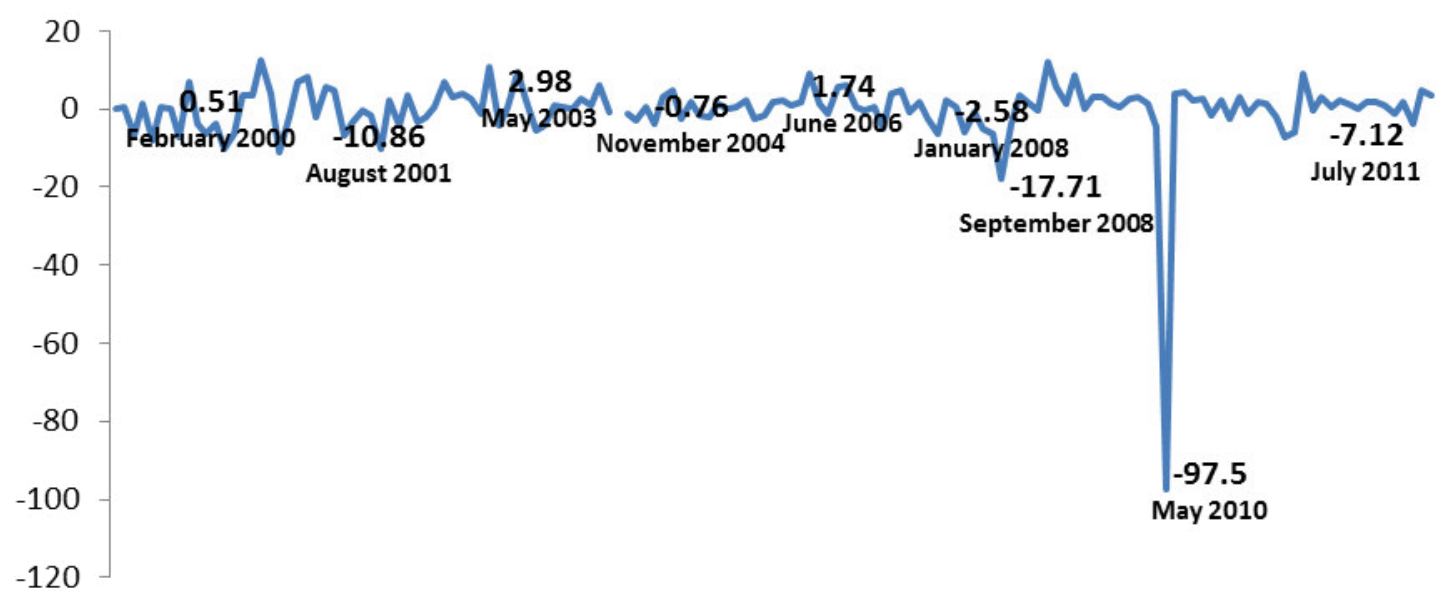


Monthly return for Kuala Lumpur Shari'ah compliance was showing stability although in year 2008 and 2010 there was some decreasing point. Looking back at that year there was national election in Malaysia (2008) and several bombing that happened in praying places (2010), although Malaysian society is very sensitive towards the increasing of oil prices, the monthly return showed no reaction at 1.74 point. From the behavioural perspective we can see that investor in Kuala Lumpur Shari'ah Compliance were more prone to the social and political condition in their country including global financial crisis that surely bring severe impact to the investing condition.

Return data has been tested for unit roots employing the augmented Dickey-Fuller (ADF) test. The results of the ADF test, presented in table 1, leads to rejection of the hypothesis of a unit root, so that the monthly in Indonesia and Kuala Lumpur Shari'ah compliance returns series can be taken to be stationary.

Table 1

Test for unit roots for Indonesia Shari'ah Compliance (ISC) and Kuala Lumpur Shari'ah compliance (KLSC)

\begin{tabular}{|c|c|c|c|c|}
\hline & \multicolumn{2}{|c|}{ ADF With Constant } & \multicolumn{2}{|c|}{ ADF Without Constant } \\
\hline & ISC & KLSC & ISC & KLSC \\
\hline $1 \mathrm{Lag}$ & $\begin{array}{l}-09.5882 \\
(6.339 \mathrm{e}-024) * * *\end{array}$ & $\begin{array}{l}-10.5643 \\
(6.738 \mathrm{e}-028)^{* * *}\end{array}$ & $\begin{array}{l}-11.7343 \\
(7.683 \mathrm{e}-025)^{* * * *}\end{array}$ & $\begin{array}{l}-9.9836 \\
(9.764 \mathrm{e}-034) * * *\end{array}$ \\
\hline $5 \mathrm{Lag}$ & $\begin{array}{l}-6.38915 \\
(1.726 \mathrm{e}-011) * * *\end{array}$ & $\begin{array}{l}-8.23940 \\
(1.834 \mathrm{e}-001) * * *\end{array}$ & $\begin{array}{l}-7.46633 \\
(1.71 \mathrm{e}-011) * * *\end{array}$ & $\begin{array}{l}-6.56453 \\
(1.71 \mathrm{e}-043) * * *\end{array}$ \\
\hline $10 \mathrm{Lag}$ & $\begin{array}{l}-3.96975 \\
(9.861 \mathrm{e}-007) * * *\end{array}$ & $\begin{array}{l}-5.674543 \\
(8.872 \mathrm{e}-016)^{* * *}\end{array}$ & $\begin{array}{l}-5.02877 \\
(1.782 \mathrm{e}-005)^{* * * *}\end{array}$ & $\begin{array}{l}-5.08733 \\
(1.756 \mathrm{e} .004)^{* * *}\end{array}$ \\
\hline
\end{tabular}

Note: figures in the parentheses show p-values. $* * *$ indicates significant at $1 \%$ level.

Table 2

Summary Statistics of Monthly Returns Indonesia Shari'ah compliance

\begin{tabular}{ccccccc}
\hline Statistics & Observations & Mean & $\boldsymbol{t}$-stats & Variance & Skewness & Kurtosis \\
\hline January & 289 & -0.0186 & -0.2213 & 0.5576 & 1.2512 & 4.2594 \\
February & 231 & -0.0221 & -0.1626 & 0.2183 & -2.8137 & 11.2397 \\
March & 242 & -0.0022 & -0.2893 & 0.3134 & -0.0844 & 1.8952 \\
April & 231 & -0.0125 & -0.2344 & 0.2137 & -0.2885 & 1.7653 \\
May & 242 & 0.0252 & -0.0831 & 0.2396 & 1.0748 & 2.3908 \\
June & 231 & 0.0506 & -0.0804 & 0.2859 & 1.0064 & 1.4775 \\
July & 220 & -0.0081 & -0.1431 & 0.1879 & 0.6904 & 0.3974 \\
August & 187 & 0.0109 & -0.1566 & 0.1696 & 0.016 & 1.7085 \\
September & 242 & 0.0271 & -0.0618 & 0.3159 & 2.7519 & 10.188 \\
October & 241 & 0.0413 & -0.1521 & 0.5692 & 2.9903 & 12.9692 \\
November & 242 & 0.0191 & -0.1714 & 0.2546 & 0.6453 & 0.4085 \\
December & 231 & -0.0046 & -0.2671 & 0.1469 & -2.6359 & 11.4431 \\
\hline
\end{tabular}

Table 2 provides a summary of statistics on the mean returns for each month of Indonesia Shari'ah compliance. The descriptive statistics run for the whole periods : 2000-2010. The results showed that mean return for Indonesia is positive in the month of May, June, August, September, October and November while the rest of the month is showed negative returns, while March suffers lowest return, June observes the highest return in stock market in 
Indonesia Shari'ah Market. Returns exhibit negative skewness (i.e., data are skewed to the left) for four months and positive skewness (i.e., data are skewed to the right) for eight months. Five months have kurtosis greater than three which represents leptokurtic distribution, i.e., flatter tails than the normal distribution.

Table 3

Summary Statistics of Monthly Returns Kuala Lumpur Shari'ah compliance

\begin{tabular}{ccccccc}
\hline Statistics & Observations & Mean & t-stats & Variance & Skewness & Kurtosis \\
\hline January & 198 & 0.03226 & -0.02603 & 0.02124 & -0.7388 & 7.8385 \\
February & 209 & -0.01322 & -0.01350 & 0.01378 & -0.3467 & 5.3195 \\
March & 231 & -0.01444 & -0.01211 & 0.00872 & -0.5260 & 10.797 \\
April & 242 & -0.01327 & -0.07890 & 0.01210 & -0.1227 & 5.7002 \\
May & 242 & -0.01704 & 0.02123 & 0.01316 & -0.2084 & 6.1468 \\
June & 231 & -0.00550 & 0.03271 & 0.01295 & -0.0804 & 7.5173 \\
July & 220 & -0.01062 & 0.01791 & 0.01486 & -0.8530 & 7.2839 \\
August & 209 & -0.01421 & 0.01867 & 0.01731 & -0.3603 & 7.6900 \\
September & 231 & 0.01295 & 0.01951 & 0.00886 & -0.4229 & 7.1434 \\
October & 242 & 0.01286 & 0.04460 & 0.01583 & -0.4008 & 8.4188 \\
November & 231 & 0.01731 & 0.02112 & 0.01173 & -0.1519 & 11.346 \\
December & 165 & 0.00686 & -0.01622 & 0.01568 & -0.4416 & 5.8470 \\
\hline
\end{tabular}

Table 3 provides a summary of statistics on the mean returns for each month of Malaysia Shari'ah compliance. The descriptive statistics run for the whole periods : 2000-2010. The results showed that mean return for Malaysia Shari'ah compliance is positive in the month of January, September, October, November and December. while the rest of the month is showed negative returns, while June suffers lowest return, January observes the highest return in stock market in Malaysia Shari'ah compliance. Returns exhibit negative skewness (i.e., data are skewed to the left) for four months and positive skewness (i.e., data are skewed to the right) for eight months. Five months have kurtosis greater than three which represents leptokurtic distribution, i.e., flatter tails than the normal distribution.

Table 4

Regression analysis for period 2000-2012 (dependent variable: logarithmic return) Indonesia Shariah Compliance

\begin{tabular}{ccccc}
\hline & Coefficient & Std. Error & t-ratio & $p$-value \\
\hline Intercept (C) & -0.0332656 & 0.0214116 & -0.5163 & 0.26295 \\
DFebruary & -0.0233915 & 0.0325412 & -0.6374 & 0.41281 \\
DMarch & 0.0312119 & 0.0125851 & 0.2205 & 0.42111 \\
DApril & -0.0112227 & 0.0140731 & -0.0612 & 0.83204 \\
DMay & -0.0313121 & 0.0340714 & -1.0508 & 0.25460 \\
DJune & -0.0233192 & 0.0060752 & -0.4865 & 0.65810 \\
DJuly & 0.0120816 & 0.693472 & 0.7944 & 0.48119 \\
DAugust & 0.0454851 & 0.0342541 & -0.1163 & 0.59969 \\
DSeptember & -0.0232023 & 0.0340752 & -0.0140 & 0.88991 \\
DOctober & 0.0480856 & -0.0340752 & 1.0432 & 0.20911 \\
DNovember & -0.0310151 & 0.0360752 & -0.7100 & 0.35473 \\
DDecember & -0.0321086 & 0.0875114 & -1.3249 & 0.12942 \\
R-squared & 0.1321742 & & Adjusted R-squared & 0.02225 \\
& & & &
\end{tabular}


Table 4 shows regression results for the partial sample period January, 2000 to December, 2012. In this sample period, the mean return for January is negative while the July effect is positively stand out and reliable. This result showed that January effect is not exist in Indonesia Shari'ah compliance and investor were not influence to effect and event that happened around december until January. The result also parallel with the theory of Efficient Market Hypothesis where is no investor could earn abnormal profit during certain month or taking advantages towards new information that arrives in certain month.

Table 5

Regression analysis for period 2000-2012 (dependent variable: logarithmic return) Kuala Lumpur Shariah Compliance

\begin{tabular}{cllll}
\hline & \multicolumn{1}{c}{ Coefficient } & \multicolumn{1}{c}{ Std. Error } & \multicolumn{1}{c}{ t-ratio } & \multicolumn{1}{c}{$\boldsymbol{p}$-value } \\
\hline Intercept (C) & -0.00892203 & 0.0322269 & -0.3082 & 0.65272 \\
DFebruary & -0.00633712 & 0.1310779 & -0.3231 & 0.70715 \\
DMarch & -0.00611287 & 0.1210778 & -0.2358 & 0.81377 \\
DApril & 0.00236818 & 0.0310889 & -0.0653 & 0.54915 \\
DMay & 0.01332322 & 0.0411779 & -0.6692 & 0.34657 \\
DJune & 0.543435623 & -0.021077 & 0.0448 & 0.04165 \\
DJuly & 0.0123706 & 0.0332779 & -0.0220 & 0.88043 \\
DAugust & 0.0251077 & 0.0410877 & 0.3833 & 0.56939 \\
DSeptember & 0.024021 & 0.0210669 & 1.0241 & 0.21251 \\
DOctober & 0.0564435 & -0.0210669 & 1.5430 & 0.65290 \\
DNovember & 0.5644554 & 0.0891669 & 0.3428 & 0.54357 \\
DDecember & -0.8383415 & 0.0326196 & -0.0956 & 0.9237 \\
R-squared & 0.34804 & & Adjusted R-squared & 0.00289
\end{tabular}

Note: $* * *$ indicates significant at $1 \%$ level; $* *$ indicates significant at $5 \%$ level; * indicates significant at $10 \%$ level.

Table 5 shows regression result for the partial sample period January, 2000 to December, 2012. In this sample period, the mean return for January is negative while the September, October and November effect positively stand out and reliable. The result of Kuala Lumpur Shari'ah compliance also the same with Indonesia Shari'ah compliance that the existence of January effect is non existence, although in July, august, september and november investor could earn profit above abnormal return, which also against the Efficient Market Hypothesis.

Through the period of 2000-2012, January anomaly in Indonesia Shari'ah Compliance is not found. Although during the sample period, mean stock return in December to April was negative. April is the first month of the financial year in Indonesia, and the absence of significant positive return in July rejects usefulness of tax-loss selling hypothesis. The same result also came from the Kuala Lumpur Shari'ah compliance where January effect is not found, although first month of the financial year start at January in Malaysia.

However, there are significant positive June anomaly in Indonesia Shari'ah Compliance and April anomaly for Kuala Lumpur Shari'ah compliance. Both result are parallel with Efficient Market Hypothesis. The existence of significicant positive in July for Indonesia Shari'ah Complianve and September, October and November for Kuala Lumpur Shari'ah compliance showed that investor enables to forecast future stoc prices by observing the current trend in stock market and can devise investment strategies which may help them to outperform the market. 


\section{Conclusion}

To explain the non existence of January effect in Indonesia Shari'ah compliance, we can give several explanation; First, from behavioural perspective or more known as holiday pyschology, this term more related or against to the Efficient Market Hypothesis, where during holiday investor tend to taking a break from investing activity which is happened in christmas holiday followed with the new year holiday, and after the break, January would be a proper month to start investing, while in Indonesia and Malaysia investor tend to react normally during the holiday season. Second, investing in Shari'ah compliance meaning that this compliance is more sensitive to riba or interest rather than tax, although tax is great motivation to earn benefit at the ehnd of the year, but the wash rule of 30 days expiration date does not interest investor in Shariah compliance.

\section{References}

Asteriou, D., \& Kovetsos, G. 2006. Testing for the existence of the January effect in transition economies. Applied Financial Economic Letters, 2(6), 375-381. http://dx.doi.org/10.1080/17446540600706817

Bahadur, K. C. F., \& Joshi, N. K. 2005. The Nepalese stock market: efficiency and calendar anomalies. Economic Review, 17(17).

Berges, A., Mcconnel, J. J., \& Schlarbaum, G. G. 1984. The turn of the year in Canada. Journal of Finance, 39(1), 185-192. http://dx.doi.org/10.1111/j.1540-6261.1984.tb03867.x Branch, B. 1977. A tax loss trading rule. Journal of Business, 50(2), 198-207. http://dx.doi.org/10.1086/295930

Fama, E. F. 1970. Efficient capital markets: A review of theory and empirical work. Journal of Finance, 25(2), 383-417. http://dx.doi.org/10.2307/2325486

Floros, C. 2008. The monthly and trading month effects in Greek stock market returns: 1996-2002. Managerial Finance, 34(7), 453-464. http://dx.doi.org/10.1108/03074350810874415

Fountas, S., \& Segredakis, K. N. 2002. Emerging stock markets return seasonalities: the January effect and The tax-loss selling hypothesis. Applied Financial Economics, 12(4), 291-299. http://dx.doi.org/10.1080/09603100010000839

Haugen, R. A., \& Lakonishok, J. 1988. The incredible January effect: the stock market's unsolved mystery. Homewood, Illinois: Dow Jones-Irwin.

Hellstrom, T. 2002. Trends and calendar effects in stock returns (Working Paper). Retrieved from http://www.citeseerx.ist.psu.edu/viewdoc/summary?

Horowitz, J.L., T. Loughran, and N.E. Savin, 2000, "Three Analyses of the Firm Size Premium," Journal of Empirical Finance, 7, 143-153.

Kato, K., \& Schallheim, J. S. 1985. Seasonal and size anomalies in the Japanese stock market. The Journal Of Financial and Quantitative Analysis, 20(2), 243-260. http://dx.doi.org/10.2307/2330958

Keim, D. 1983. Size-related anomalies and stock return seasonality: Further empirical evidence. Journal of Financial Economics, 12(1), 12-32. http://dx.doi.org/10.1016/0304$\underline{405 X(83) 90025-9}$ 
Maghayereh, A. 2003. Seasonality and January effect anomalies in an emerging capital market. The Arab Bank Review, 5(2), 25-32.

Mills, T. C., \& Coutts, J. A. 1995. Calendar effects in the London Stock Exchange FT-SE $\begin{array}{lllll}\text { Indices. } & \text { European Journal of } & \text { Finance, } & \text { 1(1), }\end{array}$ http://dx.doi.org/10.1080/13518479500000010

Mills, T. C., Siriopoulos, C., Markellos, R. N., \& Harizanis, D. 2000. Seasonality in the Athens Stock Exchange. Applied Economics Letters, 10(2), 137-142.

Nassir, A., \& Mohammad, S. 1987. The January effect of stocks traded on the Kuala Lumpur stock exchange: an empirical analysis. Hong Kong Journal of Business Management, 5, 33-50.

Pandey, I. M. 2002. Is there seasonality in the SENSEX monthly returns? Working Paper, No.WP 2002-09-08. Retrieved from http://www.iimahd.ernet.in/publications

Rossi, M. 2007. Calendar anomalies in stock returns: evidence from South America. Bachelor Thesis, Lappeenranta University of Technology.

Strong, N. 1992. Modelling abnormal returns: a review article. Journal of Business, Finance and Accounting, 19 (4), 533-553. 